Insignia Journal of International Relations

Vol. 7, No. 2, November 2020, 122-137

P-ISSN: 2089-1962; E-ISSN: 2597-9868

\title{
Demokrasi Brazil: Bagaimana Brazil Melewati Fase Transisi dan Membangun Konsolidasi Demokrasi?
}

\author{
Arie Hendrawan \\ Magister Ilmu Politik, Universitas Diponegoro \\ Email: arie28agustus@gmail.com \\ Bambang Tri Atmojo \\ Magister Ilmu Politik, Universitas Diponegoro \\ Email: bambangtriatmojo@students.undip.ac.id \\ Wahyu Rizki Pratama \\ Magister Ilmu Politik, Universitas Diponegoro \\ Email: wahyurizkipratama@students.undip.ac.id
}

\begin{abstract}
Abstrak
Pada tahun 2014, skor indeks demokrasi Brazil sempat menyentuh angka 7.38, tetapi kemudian terus jatuh seiring dengan krisis politik yang mendera negara terbesar di Amerika Latin tersebut. Meskipun demikian, dari segi politik dan ekonomi, Brazil masih relatif lebih mapan dibandingkan dengan negara-negara Amerika Latin lain yang dibuktikan dengan keikutsertaannya dalam grup ekonomi utama (G-20). Hal itu membuat penulis tertarik untuk menganalisis, bagaimana Brazil mampu melewati fase transisi dan membangun konsolidasi demokrasi. Penelitian ini menggunakan pendekatan kualitatif eksplanatif dengan teknik pengumpulan data melalui studi pustaka. Fase transisi demokrasi Brazil terjadi di antara masa diktator militer (1964-1985) dan masa republik baru (tahun 1985sekarang). Kronik transisi demokrasi Brazil tersebut relevan dengan faktor-faktor gelombang ketiga demokrastisasi yang dikemukakan oleh Huntington dan beberapa pendekatan lain. Selanjutnya, fase konsolidasi demokrasi Brazil dimulai sejak penerapan Konstitusi Baru Brazil pada tahun 1988. Penerapan Konstitusi Baru Brazil menjadi pintu masuk bagi konsolidasi demokrasi, sebab menciptakan pemerintahan yang lebih terbuka dan demokratis serta jaminan yang luas atas hak-hak dan demokratisasi. Jadi, syarat-syarat konsolidasi demokrasi seperti Pemilu yang bebas dan layak, pemerintahan yang demokratis, serta jaminan terhadap hak-hak individu dan partisipasi publik dapat terpenuhi dengan Konstitusi Baru sebagai landasan yuridisnya. Tantangan ke depan untuk menjaga konsolidasi demokrasi di Brazil adalah pembangunan ekonomi dan penguatan integritas pemerintah. Di samping itu, kebangkitan kelompok populisme sayap kanan juga perlu diwaspadai, sebab dapat berpotensi mengembalikan demokrasi Brazil pada fase otoriter.
\end{abstract}

Kata kunci: Brazil, transisi demokrasi, konsolidasi demokrasi

\section{Abstract}

In 2014, Brazil's democratic index score touched 7.38 but then continued to fall in line with political crisis that plagued the largest country in Latin America. However, in terms of politics and economics, Brazil is still relatively more established compared to other Latin American countries as evidenced by its participation in the main economic groups (G-20). That makes writer interested in analyzing how Brazil can go through a transition phase and build democratic consolidation. This research uses an explanative qualitative approach with data collection techniques through a literature study. Brazil's transition phase of democracy took place between the military dictatorship period (19641985) and the new republic era (1985-present). The chronicle of Brazil's democratic transition is relevant to the factors of third wave of democratization put forward by Huntington and several other approaches. Furthermore, consolidation phase of Brazil's democracy began since adoption of the Brazilian New Constitution in 1988. The application of the Brazilian New Constitution became an entry point for democratic consolidation because it created a more open and 
democratic government and broad guarantees of rights and democratization. Thus, the conditions for democratic consolidation such as free and proper elections, democratic governance, and guarantees of individual rights and public participation can be fulfilled with New Constitution as a juridical basis. The challenges ahead for maintaining democratic consolidation in Brazil are economic development and strengthening the integrity of government. Besides, rise of right-wing populism also needs to be watched out, because it could potentially restore Brazil's democracy to an authoritarian phase.

Keywords: Brazil, democratic transition, democratic consolidation

\section{PENDAHULUAN}

Terpilihnya tokoh sayap kanan Brazil, Jair Bolsonaro, sebagai presiden dalam kontestasi Pemilu tahun 2018 menambah daftar panjang tren presiden dengan label "diktaktoral" sejak beberapa tahun terakhir. Sebelumnya, pada tahun 2016, Donald Trump (presiden Amerika Serikat) dan Rodrigo Duterte (Filipina) juga berhasil menjadi pemenang dalam pemilu di negaranya masing-masing. Fenomena tersebut telah dijelaskan oleh dua ilmuwan politik dari Universitas Hardvard, Steven Levisky dan Daniel Ziblatt, dalam bukunya berjudul "How Democraties Die" (2018). Mereka menyebut, bahwa saat ini kemunculan beberapa pemimpin diktator justru berasal dari hasil pemilu. Jadi, "kelunturan demokrasi" mungkin tidak lagi disebabkan oleh kudeta, melainkan karena pemimpin yang diktator (Lavitsky dan Ziblatt, 2018).

Namun, tesis dari Levisky dan Ziblatt tentang "kelunturan demokrasi" tersebut sesungguhnya juga bisa dilengkapi oleh tren kudeta gaya baru yang melibatkan parlemen di Amerika Latin dan mengancam proses konsolidasi demokrasi. Saad-Filho dan Boffo (2020) menyebutya sebagai "21st-century style coup d'etat". Seperti contoh, yang terjadi di Brazil ketika Dilma Rousseff (calon petahana) terpilih menjadi presiden Brazil secara demokratis pada tahun 2014, tetapi kemudian dilengserkan melalui pemungutan suara (voting) di parlemen pada tahun 2016. Dilma dituduh memanipulasi anggaran berdasarkan investigasi yang dikenal dengan sebutan Operasi Lava Jato (Operation Car Wash) (BBC Indonesia, 2016). Padahal, tuduhan tersebut bahkan belum diproses dan diputuskan di pengadilan. Gaya kudeta yang hampir sama saat ini juga tengah mengincar Nicolas Maduro (Venezuela) dan telah berhasil melengserkan
Evo Morales (Bolivia), meskipun pada konteks ini keduanya dicap sebagai pemimpin yang diktator.

Apabila ditarik lagi ke belakang, kudeta memang senantiasa menjadi warna tersendiri bagi konstelasi politik di negara-negara Amerika Latin. Pada dekade 1970-an dan dekade 1980-an misalnya, negara-negara di kawasan Amerika Latin jatuh ke tangan "junta militer". Selanjutnya, di tahun 1990-an, secara gradual Amerika Latin terbebas dari kediktatoran militer, tetapi rezim demokratis justru dinilai semakin memperparah kemiskinan dan jurang ketimpangan. Pada akhirnya, berbagai kudeta kembali mewarnai kancah perpolitikan negara-negara Amerika Latin, seperti terjadi di Honduras (2009), Paraguay (2012), sampai Brazil (2016).

Dari hasil kajian awal penulis, setidaknya ada tiga faktor yang menyebabkan situasi politik di Amerika Latin menjadi sangat kompleks, sehingga juga berdampak pada fluktuasi demokrasi di sana. Pertama, perebutan kekuasaan oleh tiga kelompok besar dengan spektrum berbeda-beda, yaitu partaipartai berhaluan kiri (sosialis), kelompok militer (diktator), dan partai-partai sayap kanan (liberal klasik atau konservatif). Kedua, adanya peran sentral yang sering kali dimainkan oleh pihak militer dalam ranah politik dengan derajat militerisasi yang tinggi (Hadi, 2019). Ketiga, intervensi hegemoni Amerika Serikat secara lunak melalui apa yang disebut sebagai kebijakan "covert action" (operasi rahasia). Tidak dipungkiri, banyak aksi kudeta yang terjadi di negara-negara Amerika Latin disponsori oleh pemerintah Amerika Serikat, seperti di Brazil (1964) dan Chile (1973) (Mahajan, 2005).

Brazil adalah salah satu negara dengan 
sistem politik demokrasi di Amerika Latin. Menurut kajian The Democracy Index yang dirilis oleh Economist Intelligence Unit (EIU) pada tahun 2018, Brazil menempati posisi 50 negara paling demokratis dengan skor 6.97. Sebenarnya, skor Brazil sempat menyentuh angka 7.38 di tahun 2014, tetapi kemudian terus jatuh seiring dengan krisis politik yang mendera negara terbesar di Amerika Latin tersebut (The Economist, 2019). Meskipun demikian, dari segi politik dan ekonomi, Brazil masih relatif lebih jika mapan dibandingkan dengan negara-negara Amerika Latin lainyang dibuktikan dengan keikutsertaannya dalam grup ekonomi utama (G-20). Hal itu membuat penulis tertarik menganalisis, bagaiamana Brazil melewati fase transisi dan membangun konsolidasi demokrasi hingga seperti sekarang.

Beberapa penelitian terdahulu sebenarnya telah cukup banyak mengkaji dinamika demokrasi di Brazil, seperti Mainwaring (1986) yang melihat transisi demokrasi Brazil dengan pendekatan historiografi politik; Hewitt (1990) yang meninjau demokratisasi Brazil dari sudut pandang sosiologi agama; dan Banderan (2014) yang menganalisis pola transisi demokrasi Brazil melalui teori ekonomi-politik. Jika dibandingkan dengan penelitian-penelitian sebelumnya yang cenderung masih bersifat parsial, ruang lingkup bagi analisis demokrasi Brazil dalam artikel ini akan lebih holistik, sebab mencakup proses transisi dan sekaligus konsolidasi demokrasi. Kedua variabel tersebut tidak diletakkan secara terpisah oleh penulis, melainkan ditinjau sebagai sebuah periodisasi politik yang berkesinambungan.

Selanjutnya, perjalanan demokrasi Brazil di sini tidak hanya akan disajikan dengan menggunakan kacamata sejarah, tetapi juga diinterpretasikan dan dianalisis melalui pijakan teori-teori transisi dan konsolidasi demokrasi yang tidak terjebak oleh satu faktor dari bidang teori tertentu. Seperti misalnya, ekonomi saja, politik saja, atau budaya saja. Hal tersebut dikarenakan, baik itu transisi maupun konsolidasi demokrasi pada hakikatnya merupakan suatu proses yang kompleks, sehingga tidak mungkin hanya dipengaruhi oleh satu faktor tunggal. Terakhir, penulis dalam artikel ini juga berusaha merumuskan tantangan-tantangan bagi masa depan konsolidasi demokrasi Brazil dengan melihat konstelasi politik Brazil saat ini, secara khusus pasca terpilihnya Jair Bolsonaro sebagai Presiden Brazil yang baru.

\section{Kajian Literatur}

Transisi Demokrasi

Transisi demokrasi (demokratisasi) secara umum dapat dimaknai sebagai proses peralihan rezim non-demokratis menuju ke sistem yang lebih demokratis. Dalam konteks global, Samuel Huntington (1991) membagi demokratisasi ke dalam tiga gelombang melalui bukunya yang berjudul The Thrid Wave (Democratization in the Late Twentieth Century (1991), yaitu tahun 1828-1926 saat Revolusi Prancis dan Amerika (gelombang pertama), tahun 1943-1962 pasca kemenangan sekutu pada Perang Dunia II (gelombang kedua), dan tahun 1974 yang ditandai oleh transisi demokrasi di kawasan Amerika Latin, Asia Pasifik, dan Eropa Timur (gelombang ketiga). Meskipun dewasa ini, periodisasi tersebut telah berkembang lebih jauh, sebab ada "celah" demokratisasi yang belum dijelaskan oleh Huntington, yakni keruntuhan Uni Soviet (1989-1991) dan fenomena Arab Spring (20112012), termasuk pembalikan demokratisiasi yang terjadi di negara-negara lain.

Selanjutnya, beberapa teoritisi memiliki pandangan yang beragam dalam memahami transisi demokrasi. Ada ahli yang melihatnya dari perspektif peran kepartaian (Holmes, 1994), kedudukan eksekutif dan parlemen (Remington, 1994), pengaruh dari budaya politik (Almond dan Verba, 1984), dan ada yang melihat dari kacamata partisipasi, kompetisi, dan kebebasan politik (Sorensen, 2003) (Alkatiri, 2007: 39). Di luar pandanganpandangan itu, ada pula argumen yang mengaitkan demokratisasi dengan kapasitas ekonomi sebuah negara. Seperti gagasan Seymor M. Lipset dalam esainya berjudul Some Social Requisites of Democracy, yang menjelaskan bahwa pembangunan ekonomi 
akan mampu menghasilkan sistem demokrasi yang mapan (Witianti, 2016). Hal tersebut setidaknya tercermin dalam kasus transisi demokrasi di wilayah Amerika Latin pada tahun 1960 sampai 1970-an. Pembangunan ekonomi yang baik berhasil melegitimasi demokrasi sebagai alat bagi pembangunan negara (Hadi, 2019). Meskipun ternyata pada masa perkembangan selanjutnya, pembangunan ekonomi tidak terbukti secara mutlak berbanding lurus dengan demokratisasi. Contohnya terjadi di tahun 1970 hingga 1980-an pada wilayah Amerika Latin dan Afrika. Saat itu, kapasitas ekonomi negara tengah meningkat, tetapi sistem otoritarian junta militer justru masih terus bertahan memonopoli kekuasaan (Anderson, et al., 2001).

Sampai di sini bisa dipahami, bahwa transisi demokrasi merupakan suatu proses yang kompleks, multifaset, dan tidak bersifat linier. Berkaca dari keragaman cara pandang dalam menganalisis transisi demokrasi, Mochtar Mas'ud menawarkan tiga pendekatan yang cukup komprehensif, yaitu pendekatan modernisasionis, transisional, dan struktural (Nugroho dan Wrihantnolo, 2009). Masingmasing pendekatan tersebut memiliki fokus perhatian yang berbeda-beda. Pertama, pendekatan modernisasionis meletakkan fokus pada kondisi sosial dan ekonomi. Kedua, pendekatan transisional berfokus di proses politik dan perilaku elite. Ketiga, pendekatan struktural menekankan pada perubahan struktur kekuasaan yang mendukung demokrasi. Jika dikembangkan lebih jauh lagi sesuai dengan variasi cara pandang para teoritisi di atas, jumlah pendekatan itu dapat bertambah, salah satunya dengan pendekatan kultural (aspek budaya dan agama) yang meyakini bahwa kultur mempunyai pengaruh besar terhadap fenomena politik-pada konteks ini transisi demokrasi. Pendekatan kultural didukung oleh beberapa tokoh, seperti Clifford Geertz, Ben Anderson, serta Gabriel Almond dan Sidney Verba. Almond dan Verba sebagai tokoh prominen yang mempromosikan pendekatan kultural, melakukan studi di beberapa negara yang kemudian melahirkan buku "magnum opus" berjudul The Civic Culture (1963). Pada buku tersebut dijelaskan, bahwa budaya politik merupakan sikap individu terhadap sistem politik dan komponenkomponennya yang juga berarti sikap individu atas peranan yang dimainkan dalam sistem politik (Wahyono, 2015: 19). Pendekatan kultural ini akan digunakan penulis untuk menganalisis fase awal transisi demokrasi.

Dengan pandangan multiperspektif seperti itu, tentu akan sulit merumuskan formula baku tentang faktor-faktor yang menyebabkan transisi demokrasi. Belum lagi, ada kalanya di beberapa jenis kasus, faktorfaktor yang telah disusun oleh para ahli tersebut mengalami anomali dan distorsi. Semua itu tidak terlepas dari pernyataan penulis sebelumnya, bahwa transisi demokrasi adalah proses yang kompleks, multifaset, dan tidak selalu linier. Di sini, penulis memilih untuk mengutip pendapat Samuel Huntington yang menyatakan ada lima faktor pendorong demokratisasi-secara khusus gelombang ketiga demokratisasi-sebagai "pisau analisis" primer dalam menjelaskan transisi demokrasi di Brazil. Kelima faktor tersebut adalah: 1) penurunan legitimasi rezim otoriter, 2) pertumbuhan output ekonomi global, 3) penekanan hak-hak individu dan oposisi oleh Vatikan II, 4) faktor kontingensi regional, dan 5) faktor eksternal dari upaya demokratisasi yang dibawa oleh Uni Eropa dan Amerika Serikat (Huntington, 1991). Sejumlah faktor itu menurut penulis sangat relevan untuk menggambarkan tren demokratisasi global karena telah melihat beberapa bentuk transisi demokrasi yang dijalani lebih dari 60 negara di Eropa, Amerika Latin, Asia, dan Afrika sejak "Revolusi Bunga" di Portugal pada tahun 1974. Meskipun demikian, penulis juga tidak lantas begitu saja mengabaikan pendekatanpendekatan atau teori lain.

\section{Konsolidasi Demokrasi}

Jika transisi demokrasi melihat proses perubahan rezim non-demokratis menuju sistem yang demokratis, maka konsolidasi melihat bagaimana berbagai elemen demokrasi dapat bersatu untuk secara padu memfasilitasi 
demokratisasi. Dengan kata lain, konsolidasi demokrasi adalah fase lanjutan dari demokratisasi atau transisi demokrasi. Setelah rezim otoriter berakhir, situasi politik seringkali tidak menentu karena terjadi "chaos" dan fragmentasi sipil (Nugroho, 2001: 31). Akibatnya, konflik-konflik terbuka menjadi sulit dikendalikan, mengingat penguasa yang baru belum memiliki legitimasi secara kuat di masyarakat. Peran dari konsolidasi demokrasi adalah membangun sebuah rezim demokratis yang melembaga secara kuat dan stabil pascakeruntuhan rezim otoriter atau non demokratis. Konsolidasi demokrasi sebagai proses yang panjang juga menjadi "benteng" bagi demokrasi untuk menghindari kemungkinan pembalikan dan kegagalan dengan melengkapi kekurangan dari fase transisi demokrasi serta mengorganisir demokrasi secara berkelanjutan. Pada tahap ini, konsolidasi demokrasi tidak cukup hanya melibatkan peran elite politik, tetapi juga membutuhkan peran dari seluruh elemen bangsa sampai lapisan massa "akar rumput" (Sriyanto, 2005).

Menurut O'Donnel dan Schimitter, unsurunsur yang terlibat dalam konsolidasi demokrasi terdiri atas lembaga atau institusi politik, baik itu partai politik, elite politik, kelompok-kelompok kepentingan, maupun masyarakat politik (Nugroho, 2001: 27). Selanjutnya, untuk melengkapi hal tersebut, unsur penting lainnya adalah konsensus mengenai nilai-nilai politik bersama yang dapat merapatkan dan menyandingkan elemenelemen politik di atas menjadi satu kesatuan yang padu guna mencegah kemerosotan demokrasi (Nugroho, 2001: 27). Adapun perwujudan dari konsensus nilai-nilai politik itu bisa berupa konstitusi atau undang-undang dasar baru. Sementara itu, menurut Laurence Whitehead, suatu negara berhasil melakukan konsolidasi demokrasi secara penuh ketika sistem politik negara tersebut dapat mengakomodasi kompetisi yang sehat, partisipasi publik yang seluas-luasnya, dan kebebasan berekspresi serta berpendapat tanpa ada diskriminasi dan intimidasi (Whitehead, 1989). Pendapat Whitehead lebih menekankan pada jaminan hak-hak politik individu dalam kehidupan berbangsa.

Berikutnya, dua akademisi ilmu politik yang sering memberikan ide-ide terkait demokrasi, yakni Juan J. Linz dan Alfred C. Stepan, menjelaskan tiga prasyarat minimal yang harus dipenuhi oleh suatu negara sebelum berbicara tentang konsolidasi demokrasi. Tiga prasyarat tersebut adalah: 1) pemenang Pemilu tidak menggunakan kekuatan monopolistis, 2) transisi demokrasi harus diselesaikan dengan Pemilu yang bebas dan layak, serta 3) pemimpin harus memerintah secara demokratis, tidak hanya dipilih secara demokratis (Linz dan Stepan, 1996: 14). Di samping itu, Juan J. Linz dan Alfred C. Stepan juga menambahkan lima syarat lain yang saling berhubungan dan memperkuat agar demokrasi dapat dikonsolidasikan: 1) masyarakat sipil yang bebas dan aktif, 2) masyarakat politik yang relatif otonom, 3) aktor politik utama (pemerintah dan aparatur negara) tunduk terhadap aturan yang melindungi warga negara, 4) birokrasi yang dapat digunakan oleh pemerintah demokratis yang baru, dan 5) masyarakat ekonomi baru yang dilembagakan, bukan ekonomi komando atau ekonomi pasar (Linz dan Stepan, 1996: 15).

Sementara itu, terkait pendekatan dalam memahami konsolidasi demokrasi, Goran Hyden menawarkan empat pendekatan yang mengkompilasikan teori-teori dari para ilmuwan politik lain. Pertama, pendekatan elite-agen yang berfokus pada interaksi elite politik, seperti transisi rezim dan desain konstitusi baru. Kedua, pendekatan agenmassa yang menekankan pada aspek budaya politik dan gerakan sosial. Ketiga, pendekatan massa-struktur yang melihat tingkat dan kualitas pembangunan ekonomi. Keempat, pendekatan struktur-elite yang meletakkan perhatian pada reformasi ekonomi (Hyden, 2002: 2). Tidak begitu jauh berbeda dengan pendekatan-pendekatan yang diajukan oleh Goran Hyden, Larry Diamond juga memiliki empat pendekatan dalam mengkaji fenomena konsolidasi demokrasi, yaitu: 1) pendekatan elite (aktor) yang mengedepankan komitmen antar elite melalui mekanisme koordinasi 
tertentu; 2) pendekatan institusional yang berupaya melakukan institusionalisasi politik dalam rangka pendalaman demokrasi; 3) pendekatan budaya politik yang terkait dengan persepsi, sikap, dan dukungan terhadap demokrasi yang legitimatif; dan 4) pendekatan kewargaan yang menekankan pada eksistensi masyarakat sipil (Diamond, 2003: xviii - xxiv).

Berdasarkan uraian di atas, sama seperti halnya pada studi pustaka tentang transisi demokrasi, ada banyak formula untuk menjelaskan proses konsolidasi demokrasi. Namun sejatinya, berbagai formula tersebut memiliki signifikansi masing-masing yang melihat konsolidasi demokrasi dari beragam perspektif. Seperti O'Donnel dan Schimitter yang menyebut unsur-unsur dalam konsolidasi demokrasi, Linz dan Stepan yang mengajukan prasyarat minimal dan tambahan untuk membangun konsolidasi demokrasi, dan Goran Hyden serta Larry Diamond dengan pendekatan-pendekatan teoretis untuk menjelaskan konsolidasi demokrasi. Meskipun demikian, di sini penulis akan menggunakan pemikiran Juan J. Linz dan Alfred C. Stepan tentang prasyarat minimal dan tambahan dalam konsolidasi demokrasi sebagai alat analisis utama untuk mengkaji konsolidasi demokrasi Brazil. Jika dibandingkan dengan uraian dari para akademisi lain, argumentasi Linz dan Stepan yang paling praktis dan bernas untuk menjawab mengapa dan bagaimana Brazil membangun konsolidasi demokrasi. Syarat-syarat konsolidasi demokrasi yang dikemukakan oleh Linz dan Stepan juga sangat relevan dengan hasil temuan awal penulis tentang fenomena konsolidasi demokrasi di Brazil. Akan tetapi, hal itu juga tidak lantas menyingkirkan pemikiran-pemikiran lain sebagai pisau analisis untuk menjelaskan fenomena konsolidasi demokrasi.

\section{Metode Penelitian}

Metode penelitian dalam artikel ini menggunakan pendekatan kualitatif eksplanatif dengan teknik pengumpulan data melalui studi pustaka (library research). Unit analisisnya tentang bagaimana Brazil dapat melewati fase transisi dan membangun konsolidasi demokrasi. Sementara itu, unit eksplanasinya terdiri atas faktor-faktor internal dan eksternal pendorong transisi serta konsolidasi demokrasi, seperti penurunan legitimasi rezim otoriter, pengesahan konstitusi baru, penekanan hak-hak individu dan oposisi, pemilu yang demokratis, serta masyarakat sipil yang bebas dan aktif. Meskipun unit eksplanasinya beragam, titik tekan penulis terletak pada tingkat negara bangsa. Jadi, di sini analisis yang digunakan adalah analisis korelasional. Sumber data diperoleh penulis dari berbagai literatur, seperti buku, jurnal, laporan penelitian, working paper, ensiklopedia, berita, dan artikel online yang berkaitan dengan permasalahan dan pertanyaan penelitian. Data-data dan fenomena mengenai dinamika demokrasi, konstelasi politik, serta suksesi rezim kepemimpinan di Brazil yang didapatkan oleh penulis, kemudian diinterpretasikan, dielaborasikan bersama kajian pustaka, dan disimpulkan, sehingga mampu menjawab rumusan masalah penelitian secara eksplanatif (Lamont, 2015). Jadi, teknik analisis data yang digunakan di sini adalah kualitatif interpretatif yang melihat data dan fenomena dengan basis teoretis yang kuat untuk menjelaskan suatu realitas politik secara historikal maupun kontekstual.

\section{HASIL DAN PEMBAHASAN Transisi Demokrasi di Brazil}

Sebagai fondasi dalam menganalisis transisi demokrasi di Brazil, penulis merasa perlu terlebih dahulu menyajikan gambaran sejarah dari perjalanan pemerintahan Brazil. Negara yang terletak di bagian tengah dan timur Amerika Selatan tersebut telah menjadi wilayah jajahan Portugis sejak tahun 1494. Brazil meraih kemerdekaannya pada tanggal 7 September 1822. Kemudian, pada tahun 1889 sistem pemerintahannya berubah dari sistem monarki menjadi republik. Sebelum sampai di periode republik baru seperti saat ini, Brazil melewati empat era sejarah. Keempat era sejarah tersebut terdiri atas: 1) masa republik lama (1889-1930) dengan dominasi oligarki, 2) masa Vargas (1930-1946) di bawah Getulio 
Vargas, 3) masa republik kedua (1945-1961) yang ditandai "kudeta militer" dan instabilitas politik, dan 4) masa diktator militer (19641985) saat Brazil dikuasai oleh pemimpin angkatan bersenjata (Duran, 2014). Adapun, era Republik Baru Brazil dimulai pada tahun 1985 sampai sekarang yang diawali oleh terpilihnya Tancredo Neves sebagai presiden pertama Brazil dari kalangan sipil sejak tahun 1964.

Berdasakan uraian historis di atas, bisa ditarik simpulan awal bahwa era transisi demokrasi Brazil terjadi di antara masa diktator militer (1964-1985) dan masa republik baru (1985-sekarang). Transisi demokrasi di Brazil dimulai oleh pernyataan Presiden Ernesto Geisel dan Kepala Kebinet Golbers de Couto e Silva pada Maret 1974 yang mengumumkan niat mereka untuk mempromosikan liberalisasi politik secara pelan dan hati-hati (Mainwaring, 1986). Hal tersebut sangat menarik, sebab pemerintahan yang berkuasa ketika itu adalah diktator militer. Pemerintahan diktator militer menguasai Brazil selama hampir dua puluh tahun. Rezim junta militer Brazil bahkan memberikan model bagi rezim-rezim militer dan kediktatoran lainnya di Amerika Latin dengan "Doktrin Keamanan Nasional" (Gonzales, 2011). Meskipun, pengumuman semacam itu bukan yang pertama kali keluar dari rezim militer, sebab juga pernah diumumkan di era Presiden Branco (19641967), Costa e Silva (1967-1969), dan Medici (1969-1974) (Mainwaring, 1986: 150). Namun, menjadi sangat berarti karena juga diikuti oleh sejumlah kebijakan "pelonggaran" ala Geisel.

Sejak berkuasa (1974), Geisel yang merupakan purnawirawan Jenderal Angkatan Darat memang dikenal memiliki sikap yang lebih moderat daripada Presiden Medicipendahulunya. Geisel mengambil kebijakan pelonggaran secara gradual untuk kekuasaan diktatornya dengan label abertura (pembukaan) atau distensao (dekompresi) (Baloyra, 2019). Wujud dari kebijakan tersebut salah satunya adalah saat Geisel mengizinkan partai politik opisisi Brazilian Democratic Movement (MDB) untuk berkampanye dengan bebas sebelum Pemilu November 1974 (Poll, 2020). Kebijakan Geisel yang longgar terhadap oposisi ikut didorong oleh reformasi dalam Gereja Katolik di Vatikan. Hal tersebut sesuai dengan pendapat Huntington, bahwa reformasi Gereja Katolik oleh Vatikan II yang menekankan hak-hak individu dan oposisi terhadap pemerintahan otoriter menjadi salah satu faktor pendorong gelombang transisi demokrasi (Huntington, 1991). Dampaknya, ada pergeseran pandangan dari pemerintah dunia dalam menilai pihak oposisi, secara khusus pemerintah negara-negara yang mayoritas penduduknya beragama Katolik Roma di Mediterania dan Amerika Latin, termasuk pemerintah rezim otoriter Brazil sendiri. Jadi, di sini pendekatan kultural (aspek budaya dan religi) memainkan peran yang penting untuk mamahami fase awal demokratisasi di Brazil.

Pendekatan kultural-sebagaimana namanya-meyakini bahwa kultur memiliki pengaruh yang dominan terhadap fenomena politik. Beberapa tokoh pendukung pendekatan kultural antara lain adalah Clifford Geertz, Ben Anderson, serta Gabriel Almond dan Sidney Verba. Studi dari Almond dan Verba dengan pendekatan kultural di beberapa negara kemudian juga melahirkan "magnum opus" berupa buku yang berjudul The Civic Culture (1963). Menurut Almond dan Verba, budaya politik merupakan sikap individu terhadap sistem politik dan komoponen-komponennya, serta juga dapat berarti sikap individu atas peranan yang dimainkan dalam sebuah sistem politik (Wahyono, 2015: 19). Jadi, bisa dikatakan bahwa budaya politik menyangkut orientasi psikologis dari individu terhadap objek sosial, pada kasus ini objek sosial yang dimaksud adalah sistem politik. Kemudian mengalami proses penghayatan dalam bentuk orientasi kognitif (pengetahuan dan keyakinan individu), afektif (perasaan atau ikatan-ikatan emosional), dan evaluatif (kapasitas individu menilai sistem politik). Bentuk budaya politik masyarakat sendiri dapat dipengaruhi oleh berbagai hal, mulai dari sejarah masyarakat, agama, kesukuan, hingga status sosial.

Dalam konteks fase awal transisi 
demokrasi di Brazil, faktor pendorongnya adalah "agama" yang dipicu reformasi Gereja Katolik oleh Vatikan II. Terlebih lagi, pada waktu itu Brazil merupakan negara dengan populasi Katolik (Roma) terbanyak di dunia dan sebagian besar di antaranya merupakan penganut agama yang taat. Jadi, kebijakan Geisel yang memberikan pelonggaran juga tidak terlepas dari pengaruh nilai-nilai agama dominan masyarakat Brazil tersebut dan khususnya institusi gereja Katolik sebagai salah satu faktor yang membentuk orientasi politik Geisel. Meskipun sebenarnya, secara pribadi keyakinan yang dianut oleh Geisel bukanlah Katolik Roma, melainkan Lutherian (Kristen Protestan/Evangelis). Menurut Della Cava (1988: 8), pada saat itu gereja-gereja Katolik memang mempunyai peran sentral dalam "mewakili" masyarakat sipil sebagai oposisi rezim militer. Masyarakat sipil yang dimaksud di sini adalah kumpulan individu atau organisasi yang independen dari pengaruh pemerintah. Jadi, konsep masyarakat sipil menitikberatkan pada masyarakat yang mandiri atau otonom. Masyarakat sipil menjadi entitas yang bisa membatasi dirinya dari intervensi pemerintah dan dapat senantiasa bersikap kritis dalam realitas kehidupan politik. Gereja Katolik dengan jaringan kader nasional yang luas juga menjadi satu-satunya kelompok yang mampu mengimbangi kekuatan militer dari segi kuantitas maupun kualitas. Di sini berarti, faktor agama telah mengalami amplifikasi yang melahirkan gerakan masyarakat sipil (civil society) melalui institusi Gereja Katolik. Meminjam terminologi Mansour Fakih (1999), makna masyarakat sipil pada konteks ini adalah masyarakat alternatif sebagai antitesis dari masyarakat militer (junta militer $)^{1}$. Jadi, konotasinya berbeda dengan civil society yang diperdebatkan dalam ilmu sosial.

Berikutnya, fase transisi demokrasi di Brazil berlanjut ketika Presiden Joao Figueiredo mengarahkan transfer kekuasaan kepada pemerintahan sipil (Branford \& Rocha,

\footnotetext{
1 Terminologi tersebut dikemukakan oleh Mansour Fakih dalam rangka memaknai masyarakat sipil menjelang jatuhnya rezim orde baru di Indonesia
}

1999). Dengan kata lain, Figueiredo melanjutkan kebijakan "relaksasi" Geisel, meskipun itu juga mendapatkan tentangan yang cukup besar dari kelompok militer garis keras. Di awal tahun 1980, Figueiredo membubarkan partai National Renewal Alliance Party (ARENA) dan menghapus sistem dwipartai yang berarti memungkinkan lebih banyak parai-partai baru lahir (Muller, 2012). Meskipun, ada sebuah analisis yang mengatakan bahwa keputusan tersebut diambil untuk memecah suara partai oposisi MDB yang semakin kuat (Skidmore, 1988). Pada sisi yang lain, depresi ekonomi sedang mencapai "titik klimaks" sejak krisis minyak tahun 1973 yang berakibat pada meningkatnya inflasi, pengangguran, dan utang luar negeri yang mencapai angka 90 milliar dollar kepada lembaga pemberi pinjaman internasional (Archontology, 2009). Akhirnya, pada tahun 1984 terjadi demonstrasi besar-besaran dari masyarakat. Kemudian, dalam Pemilu Presiden tahun 1985 oleh electoral college, terpilihlah Tancredo Neves sebagai presiden pertama dari kalangan sipil sejak tahun 1964 yang sekaligus menandai dimulainya era Republik Baru Brazil (Nova Republica).

Jika dianalisis, kronik transisi demokrasi Brazil saat Geisel dan Figueiredo menjabat relevan dengan sejumlah faktor gelombang ketiga demokrastisasi yang dikemukakan oleh Huntington dan beberapa pendekatan lain dalam melihat fenomena transisi demokrasi. Pertama, terkait faktor merosotnya legitimasi rezim otoriter (Huntington, 1991). Hal tersebut terjadi ketika Geisel dan Figueiredo terlilit oleh depresi ekonomi sebagai akibat dari krisis minyak dan hutang luar negeri, sehingga berdampak pada menurunnya tingkat legitimasi (keabsahan) pemerintahan militer. Penurunan itu kemudian menciptakan instabilitas politik, sebab legitimasi pemerintah merupakan sumber penting bagi ketahanan dan keberhasilan sebuah rezim. Suatu pemerintah meskipun memiliki monopoli kekuasaan, tetapi

yang sangat militeristik. Masyarakat sipil disebut sebagai masyarakat yang anti terhadap dominasi militer (kekuasaan). 
ketahanan mereka tidak hanya sebatas ditentukan oleh penggunaan kekuataan semata, melainkan juga legitimasi dari warga negara (Heywood, 2013). Oleh karenanya, semua sistem kekuasan selalu berusaha memperoleh legitimasi dari rakyat sebagai modal dalam mempertahankan kekuasaan. Rezim otoriter militer Brazil sebelumnya juga berusaha mendapatkan legitimasi. Namun, upaya tersebut dikonsolidasikan secara non demokratis melalui pemaksaan semata, tidak dengan persetujuan yang tampak dari keterlibatan warga negara dalam setiap proses politik.

Kedua, kebijakan pelonggaran Geisel dan Figueiredo bisa dianalisis dengan pendekatan transisional (Nugroho dan Wrihantnolo, 2009). Pendekatan transisional melihat, bahwa demokratisasi disebabkan oleh perubahan perilaku elite. Pendekatan itu mendapatkan afirmasi ketika Geisel dan Figueiredo sebagai pemimpin politik rezim otoriter berubah haluan dengan mengambil kebijakan pelonggaran atau relaksasi yang cenderung reformis pada saat pemerintahan militeristik berkuasa. Seperti yang telah dijelaskan sebelumnya, perubahan perilaku elite tersebut didorong oleh faktor "kultural", yaitu reformasi Gereja Katolik oleh Vatikan II yang menekankan hak-hak individu dan oposisi terhadap pemerintahan otoriter serta peran jaringan nasional gereja Katolik di Brazil sebagai representasi kekuatan masyarakat sipil dalam melawan rezim otoriter. Namun, jika dilihat dari faktor-faktor yang mempengaruhi keputusan politik, perubahan tersebut lebih berasal dari lingkungan sosial politik tidak langsung, yaitu berupa situasi atau keadaan instabil yang mempengaruhi aktor secara langsung saat akan mengambil kebijakan politik. Pada konteks ini adalah tekanan dari institusi Gereja Katolik sebagai oposisi rezim militer. Sementara itu, untuk faktor dari lingkungan sosial politik langsung adalah pemikiran reformis yang berakar dari tradisi keluarga Figueiredo. Dalam hal ini Ayahnya, Kolonel Euclides de Oliveira, yang merupakan tokoh revolusioner utama penentang kediktatoran pada masa pemerintahan
Presiden Vargas (Los Angeles Times, 1999).

Di luar faktor dan pendekatan itu, kita juga tidak boleh menafikan peran dari sistem kepartaian baru (multipartai) yang diinisiasi oleh Figueiredo dengan menghapus sistem dwipartai. Sistem multipartai melahirkan banyak partai-partai baru dan mempunyai kelebihan dalam menciptakan mekanisme pengawasan (check and balances) serta keseimbangan di internal pemerintahan yang berpotensi mengurangi absolutisme rezim otoriter, sehingga semakin memperkuat proses transisi demokrasi. Hal tersebut tampak dalam Pemilu Brazil tahun 1982, di mana 59 persen warga Brazil memilih kandidat oposisi untuk mengimbangi pemerintahan militer (Skidmore, 1988). Namun, penting pula untuk dicatat, bahwa kombinasi sistem multipartai dan presidensial yang dianut oleh Brazil juga dapat melahirkan konflik antara lembaga eksekutif dan eksekutif, sehingga memicu instabilitas politik. Hal tersebut yang kemudian terjadi pada masa kepresidenan Dilma Rousseff dengan kudeta parlemen di tahun 2016. Konflik antara eksekutif dan legislatif akan semakin buruk jika presiden yang terpilih berasal dari partai minoritas di parlemen. Di satu sisi, presiden memegang kekuasaan tunggal sebagai kepala negara dan pemerintahan, tetapi di sisi lain kekuasaan itu dikontrol secara kuat oleh parlemen dengan dibayang-bayangi ancaman pemakzulan.

Terakhir, jeratan institusi "Bretton Woods" (lembaga pemberi pinjaman luar negeri) yang secara tidak langsung melemahkan kapasitas ekonomi Brazil dan memantik gelombang besar demonstrasi rakyat juga berkontribusi terhadap proses transisi demokrasi di Brazil. Utang publik eksternal Brazil yang terus membengkak, membuat pemerintah harus memberlakukan sejumlah kebijakan pengetatan anggaran (austerity) atas desakan dari International Monetary Fund (IMF) sebagai kreditur (Galano, 1994). Meskipun demikian, situasi ekonomi Brazil tetap tidak terkendali. Puncaknya, pada tahun 1983 ketika terjadi inflasi kronis yang kemudian memobilisasi elemen masyarakat dalam gerakan demonstrasi sipil (Diretas Ja) 
(Riding, 1984). Hal ini menarik, sebab kegagalan dalam pembangunan ekonomi ternyata tidak hanya dapat menghambat demokratisasi, tetapi juga bisa mendorong transisi demokrasi. Seperti yang telah disinggung pada bagian kajian pustaka, Lipset dalam esainya Some Social Requisites of Democracy memandang, bahwa pembangunan ekonomi akan mampu menghasilkan sistem demokrasi yang mapan (Witianti, 2016). Selain itu, pembangunan ekonomi yang baik juga dianggap dapat melegitimasi demokrasi sebagai alat bagi pembangunan negara (Hadi, 2019). Artinya, untuk menjaga demokratisasi agar tetap berjalan, diperlukan pembangunan ekonomi yang berhasil. Namun di sini, jika pembangunan ekonomi tersebut gagal pada era pemerintahan otoriter, maka justru dapat mendorong transisi demokrasi. Sebaliknya, bila kapasitas ekonomi meningkat pada masa pemerintahan otoriter, maka sistem itu juga akan terus bertahan memonopoli kekuasaan, seperti terjadi di wilayah Amerika Latin dan Afrika tahun 1970 sampai 1980-an (Anderson, et al., 2001).

\section{Konsolidasi Demokrasi di Brazil}

Setelah Tancredo Neves terpilih sebagai Presiden Brazil pada tahun 1985, dinamika transisi demokrasi masih terus berlangsung. Hal tersebut tidak terlepas dari belum diamandemennya konstitusi lama Brazil (1967-1969) yang memiliki sifat-sifat executive heavy. Salah satunya dicirikan dengan kewenangan veto yang dimiliki oleh presiden, sebab rezim yang sedang berkuasa adalah rezim diktatoral militer. Di samping itu, kondisi negara belum sepenuhnya stabil pasca krisis politik dan ekonomi yang berdampak besar pada rendahnya tingkat kepercayaan masyarakat kepada pemerintah. Meskipun demikian, tahun itu telah diakui sebagai era kontemporer Brazil, yakni era Republik Baru (Nova Republica) sejak masa kekuasaan rezim militer. Menjelang pelantikan presiden tahun 1985, Tancredo Neves justru jatuh sakit yang

2 Meskipun demikian sebagai catatan khusus, dalam dimanikanya Konstitusi Baru Brazil juga sempat diwarnai oleh dua pemakzulan, yakni membuatnya tidak dapat menghadiri pelantikan. Oleh sebab itu, Jose Sarney sebagai wakilnya yang dilantik menjadi Presiden Brazil (Mainwaring, 1986: 149). Pada masa-masa awal kepemimpinan Sarney, Konstitusi Baru mulai disusun untuk menggantikan konstitusi lama. Setelah Konstitusi Baru diumumkan pada tahun 1988, di tahun 1989 Brazil mengadakan Pemilu Presiden secara langsung dan Fernando Collor (buruh-demokratik) terpilih sebagai Presiden mengalahkan Lula da Silva (buruhkiri).

Sejak diberlakukannya Konstitusi 1988 itulah, suksesi kepemimpinan Presiden Brazil relatif berjalan dengan tertib tanpa gejolak yang berarti dengan stabilitas institusional terlama sepanjang sejarah (Barroso, 2018). ${ }^{2}$ Hal tersebut menjadi fondasi penting untuk upaya membangun konsolidasi demokrasi yang berkelanjutan. Konstitusi 1988 adalah konstitusi Brazil kedelapan sejak kemerdekaan Brazil di tahun 1822. Dalam tinjauan dari Thomas C. Bruneau (Bruneau, 1990: 173), Konstitusi Baru disebut oleh sebagian besar pengamat politik Brazil sebagai "pintu masuk" bagi konsolidasi demokrasi. Peran Konstitusi Baru Brazil tersebut juga dapat dilihat dengan pendekatan agen-elit seperti yang diungkapkan oleh Hayden (2002), dang mana desain Konstitusi Baru sebagai hasil dari interaksi politik mampu membangun fase konsolidasi demokrasi. Hal itu didasarkan pada transformasi sistem pemerintahan yang lebih terbuka dan demokratis serta jaminan luas atas hak-hak dan demokratisasi berkat pemberlakukan Konstitusi Baru. Jika merujuk pendapat dari O'Donnel dan Schimitter terkait unsur-unsur konsolidasi demokrasi, Konstitusi 1988 bisa pula dianggap sebagai konsensus mengenai nilai-nilai politik bersama yang dapat merapatkan dan menyandingkan elemenelemen politik secara padu (Nugroho, 2001: 27).

Setelah Konstitusi 1988 berlaku, syaratsyarat konsolidasi demokrasi lain secara inheren juga dapat terpenuhi dengan

kepada Presiden Fernando Collor de Mello (1992) dan Presiden Dilma Rousseff (2016) yang samasama dituduh melakukan korupsi. 
Konstitusi Baru sebagai landasan yuridisnya. Pertama, Pemilu yang bebas dan demokratis. Juan J. Linz dan Alfred C. Stepan menjelaskan, bahwa salah satu prasyarat minimal bagi konsolidasi demokrasi adalah penyelesaian transisi demokrasi dengan Pemilu yang bebas dan layak (Linz dan Stepan, 1996: 14). Selanjutnya, Laurence Whitehead menyebut bahwa negara berhasil mengkonsolidasikan demokrasi secara penuh ketika suatu sistem politik negara tersebut bisa mengakomodasi kompetisi yang sehat dan partisipasi publik yang luas (Whitehead, 1989). Kedua hal itu terpenuhi dalam pelaksanaan Pemilu Presiden tahun 1989 yang diselenggarakan secara bebas dan demokratis. Menurut data International Institute for Democracy and Electoral Assistance (IDEA), Pemilu Presiden Brazil tahun 1989 menjadi Pemilu Presiden dengan tingkat kehadiran pemilih (voter turnout) tertinggi sepanjang sejarah dari tahun 1945 sampai 2018, yakni mencapai 88,07\% (International IDEA, 2019). Pemilu Presiden tahun 1989 memang benar-benar sesuai kehendak rakyat Brazil, sebab masyarakat ingin memilih calon presiden secara langsung.. Ini berbeda dengan sistem Pemilu Presiden tidak langsung yang dijalankan selama kekuasaan rezim militer, yakni melalui sebuah lembaga yang disebut "electoral college". Electoral college sendiri terdiri atas senator, deputi, dan anggota parlemen di tingkat kota.

Kedua, pengesahan Konstitusi Baru juga berdampak pada reformasi tata kelola pemerintahan Brazil yang lebih demokratis. Sejak Konstitusi Baru dilegitimasi, tidak ada lagi dominasi kekuasaan eksekutif dalam sistem pemerintahan (executive heavy), baik secara struktural maupun institusional. Hal tersebut juga sekaligus memenuhi prasyarat minimal lain bagi konsolidasi demokrasi seperti yang diungkapkan oleh Juan J. Linz dan Alfred C. Stepan, yakni pemenang Pemilu tidak boleh menggunakan kekuatan monopolistis (Linz dan Stepan, 1996: 14). Dalam tata kelola pemerintahan yang baru sesuai dengan Konstitusi 1988, pemerintah Brazil memiliki tiga cabang kekuasaan (eksekutif, legislatif, dan yudikatif) yang bersifat independen dan harmonis satu sama lain. Jadi, lembaga eksekutif tidak memegang kekuasaan monopolistis seperti halnya pada rezim militeristik. Pelembagaan secara demokratis tersebut juga menjadi bentuk dari institusionalisasi politik yang demokratis menurut Larry Diamond dalam pendekatan institusional (Diamond, 2003: xviii). Institusionalisasi politik dilakukan dengan tujuan "pendalaman demokrasi" yang membuat struktur formal demokrasi menjadi lebih bebas, akuntabel, representatif, dan aksesibel.

Dampak lain dari pengesahan Konstitusi Baru bagi konsolidasi demokrasi Brazil adalah adanya kebebasan berkespresi dan jaminan terhadap hak-hak individu. Hal tersebut sesuai dengan ciri-ciri konsolidasi demokrasi yang disampaikan oleh Laurence Whitehead tentang kebebasan berekspresi serta berpendapat tanpa diskriminasi dan intimidasi (Whitehead, 1989) serta syarat konsolidasi demokrasi menurut Linz dan Stepan terkait masyarakat sipil yang bebas dan aktif (Linz dan Stepan, 1996: 14). Wujud kebebasan tersebut misalnya membatasi intervensi negara dalam mengatur kehidupan individu. Di samping itu, Konstitusi 1988 juga menjadi konstitusi pertama yang memuat hukuman berat untuk pelanggar kebebasan dan hak sipil. Hal itu terjadi karena Konstitusi Baru Brazil memang dirancang sebagai reaksi (antitesis) terhadap periode kediktatoran militer. Terakhir, Konstitusi Baru menetapkan banyak bentuk partisipasi masyarakat selain voting dalam Pemilu secara reguler, seperti plebisit, referendum, dan kemungkinan warga biasa mengusulkan undang-undang baru.

Hambatan bagi konsolidasi demokrasi Brazil kemudian terletak pada kapabilitas pemerintahan dalam menyelesaikan masalahmasalah yang terkait krisis ekonomi, salah satunya hiperinflasi. Hiperinflasi terjadi di Brazil dari tahun 1980 sampai 1994 yang salah satunya dipicu oleh krisis energi tahun 1970-an selama masa kediktatoran militer. Pemerintah Brazil gagal mengelola tingkat inflasi, sehingga mengalami hiperinflasi mencapai lebih dari 500 persen per tahun. Puncaknya pada tahun 1990 yang mencapai hampir 3000 persen 
(Astrini, Juanda, \& Achasani, 2016: 211). Jika dianalisis, fenomena tersebut cukup menarik. Seperti yang telah dijelaskan pada bagian pembahasan tentang transisi demokrasi, di satu sisi krisis ekonomi dapat menjadi "isu bersama" yang menyatukan suara masyarakat Brazil untuk menggulingkan pemerintahan di pengujung periode rezim militer. Namun di sisi lain, jika pemerintahan demokratis yang baru belum mampu menangani persoalan krisis ekonomi, itu juga akan membuka peluang bagi kemunduran demokrasi di Brazil. Terlebih lagi pada masa kediktatoran junta militer saat presiden Medici menjabat (1969-1974), Brazil justru sempat berada di "periode emas" (Brazilian Miracle) dengan pertumbuhan ekonomi tahunan (PDB) rata-rata mendekati angka 10\% (Wilkinson, 2020).

Ketidakmampuan pemerintah Brazil dalam menangani masalah krisis ekonomi maupun pembangunan ekonomi juga akan menjadi preseden buruk bagi pemerintahan dan secara khusus bagi sistem demokratis itu sendiri. Oleh karenanya, persoalan di bidang ekonomi perlu mendapatkan perhatian yang serius dari pemerintahan demokratis Brazil ke depan demi mengupayakan konsolidasi demokrasi yang berkelanjutan. Jika stabilitas dan pertumbuhan bidang ekonomi tidak dapat dijaga, maka sikap skeptis dan pesimistis masyarakat akan muncul. Akibatnya, legitimasi warga negara kepada pemerintahan dapat menurun. Hal tersebut sangat mungkin menggagalkan proses konsolidasi dan justru menyebabkan kemunduran demokrasi. Di sini, hipotesis dari Lipset menjadi relevan, bahwa pembangunan ekonomi mampu menghasilkan demokrasi yang mapan atau melanggengkan sistem demokrasi. Terakhir, pemberantasan korupsi saat ini juga masih menjadi permasalahan serius yang belum tuntas terselesaikan di Brazil. Tercatat, tiga presiden terakhir Brazil sebelum periode kepemimpinan Bolsonaro (2019), semuanya tersangkut kasus korupsi (BBC Indonesia, 2017). Dampaknya,

\footnotetext{
${ }^{3}$ Menurut Grigera (dalam Darmawan, 2017: 4), ada tiga gelombang populisme di Amerika Latin, yaitu populisme politik-ideologis (1950-an dan 1960-an), populisme neoliberal (1990-an), dan neopopulisme/ populisme kiri
}

sebagian masyarakat memilih bersikap apatis terhadap politik, pemerintah, dan bahkan juga kecewa terhadap sistem demokrasi (Costa, 2018). Isu korupsi memang telah menjadi bagian dari semua pergolakan politik besar di Brazil sejak abad 19 (Saad-Filho dan Boffo, 2020: 4). Hal tersebut tentu akan ikut mengancam kelangsungan proses konsolidasi demokrasi di Brazil.

Kekecewaan sebagian publik Brazil terhadap sistem demokrasi saat ini sudah "termanifestasikan" dengan terpilihnya Jair Bolsonaro sebagai Presiden Brazil pada Pemilu 2018 yang dianggap mewakili gerakan rakyat anti-elit (populisme) ${ }^{3}$. Propaganda Bolsonaro dengan bantuan teknologi digital dan framing media, efektif meraup suara-khususnyadari para pemilih bimbang (swing voters) (Araujo dan Prior, 2020: 2), sebab pemerintahan sayap kiri sebelumnya banyak yang terjerat kasus korupsi dan gagal mengatasi krisis ekonomi. Bolsonaro sendiri merupakan seorang tokoh populis sayap kanan yang mencoba untuk mengintegrasikan nilainilai konservatisme, etnosentrisme, dan antielit. Nilai-nilai yang dibawa oleh Bolsonaro tersebut diterima karena dipandang sebagai antitesis dari pemerintahan "pink tide" (kelompok sayap kiri) yang terbukti gagal mengatasi krisis ekonomi dan masalah korupsi. Akan tetapi, terpilihnya Bolsonaro ikut berpotensi mengancam konsolidasi demokrasi Brazil di masa depan, sebab gerakan populisme yang dibawanya termasuk dalam jenis populisme otoriter. Hal itu tampak dari kebijakan-kebijakan publik Bolsonaro yang cenderung diktatoral dan anti-demokrasi, meskipun rezimnya dikemas secara hybrid, yakni dengan menggabungkan elemen demokratis dan otoriter (Neto, 2020: 53). Populisme otoriter sendiri memang mengharapkan pemimpin kharismatik yang lahir dari proses demokratis (Darmawan, 2017: 3). Namun, sesuai pendapat Linz dan Stephan (1996: 14), salah satu syarat bagi konsolidasi

(2000-an). Selanjutnya, sejak tahun 2015-an, gelombang populisme global-termasuk di Amerika Latin-telah bergerak cenderung ke arah kanan menjadi "populisme sayap kanan". 
demokrasi bukan hanya tentang sosok pemimpin (presiden) yang terpilih secara demokratis, tetapi juga harus dapat memerintah secara demokratis. Terlepas dari itu, naiknya tokoh populis sayap kanan ke tampuk kekuasaan diyakini akan tetap menjadi faktor fundamental dalam kehidupan sosial dan politik Brazil di tahun-tahun mendatang (Bertonha, 2020: 10).

\section{KESIMPULAN}

Berdasarkan elaborasi pembahasan di atas, ada beberapa simpulan yang dapat ditarik dalam artikel ini. Pertama, transisi demokrasi Brazil dimulai sejak era tahun 1974 yang dipicu oleh pandangan reformis Vatikan II tentang pemenuhan hak-hak individu dan oposisi. Hal tersebut sesuai pendekatan kultural, di mana faktor agama mempengaruhi orientasi politik pemerintah. Faktor lain yang menyebabkan transisi demokrasi di Brazil adalah merosotnya legitimasi rezim otoriter akibat depresi ekonomi (inflasi, hutang luar negeri, dan pengangguran yang tinggi). Selanjutnya, transisi demokrasi Brazil juga dapat dilihat dengan pendekatan transisional, yakni disebabkan perubahan perilaku elite politik karena didorong oleh faktor agama dan tekanan dari masyarakat sipil. Di samping itu, faktor lain yang tidak boleh dinafikan adalah peran kepartaian yang semakin kuat dengan penerapan sistem multipartai dan jeratan institusi Bretton Woods yang melemahkan kapasitas ekonomi Brazil serta memantik gelombang besar aksi demonstrasi.

Kedua, konsolidasi demokrasi Brazil benar-benar dimulai saat Konstitusi Baru diterapkan pada tahun 1988. Penerapan konstitusi tersebut menjadi pintu masuk bagi konsolidasi demokrasi, sebab menciptakan pemerintahan yang terbuka dan demokratis

\section{DAFTAR PUSTAKA}

\section{Buku}

Anderson, Richard D., M. Steven Fish, Stephen E. Hanson, dan Philip G. Roeder. (2001). Postcommunism and The Theory of serta jaminan yang luas atas hak-hak dan demokratisasi. Jadi, syarat-syarat konsolidasi demokrasi seperti Pemilu yang bebas dan layak, pemerintahan yang demokratis, serta jaminan terhadap hak-hak individu dan partisipasi publik dapat terpenuhi dengan Konstitusi Baru sebagai landasan yuridisnya. Tantangan yang dihadapi oleh pemerintah Brazil untuk menjaga konsolidasi demokrasi adalah membuktikan kepada seluruh masyarakat Brazil, bahwa pembangunan ekonomi dapat selaras dengan sistem demokrasi. Di samping itu, juga terus berusaha melakukan penguatan integritas dan pemberantasan korupsi.

Terakhir, yang juga penting untuk diperhatikan dalam proses konsolidasi demokrasi Brazil di masa depan adalah fenomena kebangkitan gerakan populisme sayap kanan yang tengah menjadi tren global. Di Brazil, presiden Jair Bolsonaro yang saat ini berkuasa merupakan bagian dari tren global populisme sayap kanan tersebut. Bolsonaro termasuk dalam kategori pemimpin populis otoriter. Hal itu tampak dari pandanganpandangan dan kebijakan publiknya yang ber diktatoral serta anti-demokrasi. Bolsonaro juga mengaku "rindu" terhadap kekuasaan diktatoral militer Brazil pada tahun 1964-1985. Artinya, bukan tidak mungkin ketika Bolsonaro berhasil memperoleh kepercayaan dan legitimasi yang tinggi dari masyarakat, fase konsolidasi demokrasi akan mengalami pembalikan-berbalik arah menuju fase otoriter. Penulis berharap, ke depan ada penelitian lanjutan yang lebih aktual dan spesifik untuk menganalisis dampak dari terpilihnya Jair Bolsonaro dan kebangkitan populisme sayap kanan terhadap konsolidasi demokrasi di Brazil, mengingat konsolidasi demokrasi Brazil yang masih berproses.

Democracy. New Jersey: Princeton University Press.

Baloyra, Enrique A. (2019). Comparing New

Democracies: Transition And

Consolidation In Mediterranean 
Europe And The Southern Cone. London: Routledge.

Bruneau, Thomas C. (1990). Constitutions and

Democratic Consolidation: Brazil in Comparative Perspective. Dalam D. Ethier (Ed.), Democratic Transition and Consolidation in Southern Europe, Latin America and Southeast Asia (pp. 173-96). London: Palgrave Macmillan UK.

Diamond, Larry. (2003). Developing Democracy: Toward Consolidation. Yogyakarta: IRE Press.

Heywood, Andrew. (2013). Poltik. Edisi Keempat. Yogyakarta: Pustaka Pelajar.

Huntington, Samuel. (1991). The Thrid Wave (Democratization in the Late Twentieth Century). Oklahoma: University of Oklahoma Press.

Hyden, Goran. (2002). Development and Democracy: An Overview. Dalam 0. Elgstrom dan G. Hyden (Ed.), Development and Democracy: What have We Learned and How? 1-22. London: Routledge.

Lamont, C. (2015). Research Methods in International Relations. London: SAGE Publishing.

Lavitsky, Stevel, \& Ziblatt, Daniel. (2018). How Democraties Die. New York: Crown Publishing.

Mahajan, Rahul. (2005). Melawan Negara Teroris: Dominasi Amerika Serikat Terhadap Irak \& Kedaulatan Dunia. Jakarta: Mizan Pustaka.

Muller, Tom. (2012). Political Handbook of the World. California: SAGE Publishing.

Skidmore, Thomas. (1988). The Politics of Millitary Rule in Brazil. New York, NY: Oxford University Press.

Whitehead, Laurence. (1989). The Consolidation of Fragile Democracies: A Discussion with Illustrations. Dalam Robert A. Pastor (Ed.), Democracy in the Americas: Stopping the Pendulum. New York: Holmes and Meier.

\section{Jurnal}

Alkatiri, Zeffry. (2007). Perdebatan Teori Transisi Demokrasi. Wacana: Journal of the Humanities of Indonesia, 9(1), 32-50.
Araujo, Bruno \& Prior, Helder. (2020). Framing Political Populism: The Role of Media in Framing the Election of Jair Bolsonaro. Journalism Practice, 1-17. https://doi.org/10.1080/17512786.201 9.1709881.

Astrini, D., Juanda, B., dan Achsani, N. (2016). Impact of Redenomination on Price, Volume, and Value of Transaction: An Experimental Economic Approach. Buletin Ekonomi Moneter Dan Perbankan, 19(2), 207-238.

Banderan, Suprisno. (2014). Pola Transisi Demokrasi Yang Terjadi Di Indonesia Dan Brazil. Farabi: Journal of Ushuluddin \& Islamic Thought, 11(2),100-108.

Barroso, Luis Roberto. (2018). Thirty Years of the Brazilian Constitution: The Republic That Is Yet to Be. Social Science Research Network. https://ssrn.com/abstract $=3279609$ or http://dx.doi.org/10.2139/ssrn.3279609

Costa, Andressa Vieira. (2018). Political Culture and Democracy in Latin America: Perspectives on Brazil and Colombia. Encuentro Latinoamericano, 5(1), 45-65.

Della Cava, R. (1988). The Church and the Abertura in Brazil, 1974-1985. Working Paper - Helen Kellogg Institute for International Studies, 114(11),1-32.

Darmawan, Arif. (2017). Gerakan Populis Sebagai Tren Global: Dari Amerika Latin Sampai Occupy Movement. Insignia Journal of International Relations, 4(2), 18.

Fakih, Mansour. (1999). Masyarakat Sipil; Catatan Pembuka. Jurnal Ilmu Sosial Transformatif, 1(1), 2-6.

Hadi, Kisno. (2019). Perbandingan Penegakan Demokrasi Di Indonesia Pasca-Rezim Suharto Dan Filipina Pasca-Rezim Marcos. Insignia Journal of International Relations, 6(1),13-29.

Hewitt, W. E. (1990). Religion and the Consolidation of Democracy in Brazil: The Role of the Comunidades Eclesiais de Base (CEBs). Sociology of Religion, 51(2), 13952. 
Linz, Juan J., \& Stepan, Alfred. (1996). Toward Consolidated Democracies. Journal of Democracy, 7(2),14-33.

Mainwaring, Scot. (1986). The Transition to Democracy in Brazil. Journal of Interamerican Studies and World Affairs, 28(1), 267-314.

Neto, Ulisses Terto. (2020). Bolsonaro, Populism and the Fascist Threat: The Role of Human Rights Defenders in Protecting Brazilian Democracy. Kairos: A Journal of Critical Symposium, 5(1), 47-66.

Nugroho, Kris. (2001). Konsolidasi Demokrasi. Jurnal Masyarakat, Kebudayaan, dan Politik, 14(2), 25-34.

Saad-Filho, Alfredo, dan Boffo, Marco. (2020). The corruption of democracy: Corruption scandals, class alliances, and political authoritarianism in Brazil. Geoforum, 110.

DOI: https://doi.org/10.1016/j.geoforum.202 0.02.003.

Sriyanto, Nanto. (2005). Kritik Atas Determinisme Dalam Model Transisi Demokrasi. Jurnal Penelitian Politik, 2(1), 3-11.

Wahyono, Sugeng Bayu. (2015). Transformasi Kultural Menuju Demokrasi Substansial. Jurnal Pemikiran Sosiologi, 1(1), 16-29.

Witianti, Siti. (2016). Demokrasi Dan Pembangunan. Jurnal Wacana Politik, 1(1), 71-76.

\section{Artikel Daring}

Archontology. (2009, 26 Juni). "João Baptista de Oliveira Figueiredo". Diakses dari http://www.archontology.org/nations/b raz/braz_rep3/figueiredo.php.

BBC Indonesia. (2016, 1 September). "Dilma

Rousseff Dimakzulkan Melalui

Pemungutan Suara Di Senat Brasil."

Diakses dari

https://www.bbc.com/indonesia/dunia/ 2016/08/160831_dunia_brasil_dilma.

BBC Indonesia. (2017, 13 Juli). "Hukuman

Penjara Untuk Mantan Presiden

Brasil, Lula." Diakses dari

https://www.bbc.com/indonesia/du nia-40589180.
Bertonha, Joao Fabio. (2020, Mei). "Radical Right Ideologies dan Movement in Brazil." Oxford Research Encyclopedias, Latin American History. Diakses dari https://oxfordre.com/latinamericanh istory/view/10.1093/acrefore/9780 199366439.001.0001/acrefore9780199366439-e-841.

Branford, Sue, \& Rocha, Jan. (1999, 28 Desember). "Joao Figueiredo (Hapless Soldier Caught in Brazil's Search for Reform." The Guardian. Diakses dari https://www.theguardian.com/news /1999/dec/29/guardianobituaries2.

Duran, Rebeca. (2014, 13 Februari).

"History of Brazil Republic." The Brazil Business. Diakses dari https://thebrazilbusiness.com/articl e/history-of-brazil-republic.

Gonzales, Eduardo. (2011, 12 Juni). "Brazil Shatters Its Wall of Silence on the Past." ICTJ. Diakses dari https://www.ictj.org/news/brazilshatters-its-wall-silence-past.

International IDEA. (2019). "Voter Turnout by Election Type (Brazil)". Diakses dari https://www.idea.int/datatools/country-view/68/40.

Los Angeles Times. (1999, 25 Desember). "Joao Figueiredo; Ended Military Rule in Brazil". Diakses dari https://www.latimes.com/archives/laxpm-1999-dec-25-mn-47430-story.html. Nugroho, Riant, dan Wrihantnolo, Rendy R. (2009, 13 Oktober). Bappenas RI. "Demokrasi Bagi Negara-Negara Berkembang." Diakses dari https:/www.bappenas.go.id/files/3213/ 5028/6740/02mustopadidjaja _20091014125643_2248_0.pdf.

Poll, Michael. (2020, 31 Mei). "Distensão.” Encyclopedia of Latin American History and Culture. Diakses dari https://www.encyclopedia.com/hum anities/encyclopedias-almanacstranscripts-and-maps/distensao.

Riding, Alan. (2020, 23 September). "Direct Vote Demanded For Brazil." The New 
York Times. Diakses dari

https://www.nytimes.com/1984/02/19

/world/direct-vote-demanded-forbrazil.html.

The Economist. (2019). "The Economist Intelligence Unit's Democracy Index.” Diakses dari https://infographics.economist.com/ 2019/DemocracyIndex/.
Wilkinson, Ross. (2020, 22 Mei). "Brazil, Economic Miracle (1968-1974).” Encyclopedia of Latin American History and Culture. Diakses dari https://www.encyclopedia.com/hum anities/encyclopedias-almanacstranscripts-and-maps/brazileconomic-miracle-1968-1974. 